\title{
Polycyclic Aromatic Hydrocarbons in the Particles Emitted from the Diesel and Gasoline Engines
}

\author{
Małgorzata Szewczyńska ${ }^{1 *}$, Joanna Dąbrowska², Krystyna Pyrzyńska ${ }^{3}$ \\ ${ }^{1}$ Centralny Instytut Ochrony Pracy- PIB, Czerniakowska 16, 00-701 Warszawa, Poland \\ ${ }^{2}$ University of Warsaw, Chemistry Department, Pasteura 1, 02-093 Warsaw, Poland \\ ${ }^{3}$ University of Warsaw, Chemistry Department, Pasteura 1, 02-093 Warsaw, Poland
}

Received: 23 June 2016

Accepted: 30 August 2016

\begin{abstract}
Polycyclic aromatic hydrocarbons (PAHs) are contaminants widespread in the environment and vehicular emissions have long been recognized as the most important anthropogenic sources of PAHs in urban air Polycyclic aromatic hydrocarbons (PAHs) emitted in the exhaust gases of diesel and petrol engines using different fuels were quantified. Size fractionated chemical analysis of particles in vehicle emissions were carried out by sampling with an electrical low pressure multi-stage impactor ELPI. The mean concentrations of total PAHs adsorbed onto the particulate matter in the rage of $0.03-0.25 \mu \mathrm{m}$ emitted from the exhaust gases were 48.3, 128.2 and $83.0 \mathrm{ng} \cdot \mathrm{m}^{-3}$, respectively from three kinds of diesel fuels. Results indicated that PAHs present in the last two fraction $(0.17-0.25 \mu \mathrm{m})$ have the highest contribution in the total content of these compounds. In the collected fractions of particulate matter emitted in gasoline engine exhaust 12 compounds were identified in the $0.25 \mu \mathrm{m}$ fraction and 9 PAHs in the $0.17 \mu \mathrm{m}$ fraction.
\end{abstract}

Keywords: PAHs, exhaust gases, diesel and petrol engines, anthropogenic sources, particular matter

\section{Introduction}

Emissions from motor vehicles have substantially changed over the last decade because of new fuels, changed engine designs, and improved emission-control technology. Engine exhaust gases form a mixture of substances in various states. Gases are dominant, but liquids and solids from incomplete combustion of fuel and engine oil are also present. Particulate matter (PM) emitted from diesel and gasoline engines is a mixture of

*e-mail: mapol@ciop.pl soot and soluble organic fraction, which is composed of an aromatic fraction resulting from unburned hydrocarbons (benzene, toluene, styrene, xylene) from the paraffin acidic phase (cresol, benzoic acid) and the alkaline phase (pyridine, aniline). The remaining components adsorbed at the carbon core include inter alia water-soluble sulphates, nitrates, metals, and other carbon particulates. The concentrations, modal structures, and temporal patterns of urban particles are strongly influenced by traffic emissions, which are identified as the main source of particle number in urban environments [1].

Polycyclic aromatic hydrocarbons (PAHs) are contaminants widespread in the environment, and vehicular emissions have long been recognized as the 
most important anthropogenic sources of PAHs in urban air [2]. They are mainly derived from the incomplete combustion of fossil fuels, wood, and biomass, and from the volatilization of petroleum products. Once released into the air, gaseous and particle-bound PAHs can be transported over a long distance and transferred to other environmental media such as surface soil and water. Due to the carcinogenicity and mutagenicity of some of these compounds - particularly those containing four or more aromatic rings - they have been included in the European Union priority lists of pollutants [3].

Particulate matter with dimensions of $0.1-0.5 \mu \mathrm{m}$ are very easily absorbed by the body and accumulated within the pulmonary alveoli. They may remain there for hundreds of days, which leads to chronic pulmonary trouble and has a potential carcinogenic effect $[4,5]$. In the case of acute exposure, the exhaust gases irritate the oral and upper respiratory tract mucosa, cause headaches, vertigo, and tiredness, as well as nausea. The aerodynamic size of the particulates has an impact on their absorption and accumulation in the body [6].

During recent decades, continuous concern has been raised with respect to PM emitted during the operation of motor vehicles, mainly by diesel engines [7-13]. The World Health Organization (WHO) has reported that diesel engine exhaust is classified as carcinogenic to humans [14]. To assess the potential health hazards resulting from inhalation of PM emitted from engines, it is important to establish their qualitative and quantitative composition and to establish the distribution of hazardous substances in individual fractions, as the aerodynamic size of the particulates has an impact on their absorption and accumulation in the body.

It can be assumed that the concentrations of polycyclic aromatic hydrocarbons and their toxic effects will vary depending on particle size. These of the smallest size are possibly the most important source of PAHs, because the number concentration of particles dominates, and they have the largest specific surface area. The operating conditions of the engine, including its power, speed, and the exhaust gas temperature as well as the properties of the fuel itself (e.g., sulphur content, density, distillation point, and octane index) may have an impact on the chemical composition of the exhaust gases and the aerodynamic distribution of particulate matter [14-19]. Therefore, in this paper particulates were collected from diesel and petrol engines running on three different fuels each. Consider- ing the increasing importance of small airborne particles for exposure assessment, the objective of this study was to characterize and quantify the main pollutants (i.e., PAHs) emitted in the exhaust gases of diesel and petrol engines. Size fractionated chemical analyses of particles in vehicle emissions were carried out by sampling with an electrical low pressure multi-stage electrical low-pressure impactor (ELPI; Dekati, Finland).

\section{Materials and Methods}

\section{Chemicals}

Standard PAH mixture and corresponding individual compounds were obtained from Supelco. The standard PAH mixture (EPA 610 Polynuclear Aromatic Hydrocarbons Mix 100-2,000 $\mu \mathrm{g} / \mathrm{mL}$ in $\mathrm{MeOH}: \mathrm{CH}_{2} \mathrm{Cl}_{2}, 1: 1 \mathrm{v} / \mathrm{v}$ ) contained naphthalene (NA), acenaphtene (AC), fluorene (FL), phenanthrene $(\mathrm{PH})$, anthracene $(\mathrm{AN})$, fluoranthene (FLR), pyrene $(\mathrm{PH})$, benzo $(a)$ anthracene $(\mathrm{B} a \mathrm{~A})$ : chrysene $(\mathrm{CH})$, benzo $(b)$ fluoranthene $(\mathrm{B} b \mathrm{~F})$, benzo $(k)$ fluoranthene $(\mathrm{B} k \mathrm{~F})$, dibenzo $(a h)$ anthracene (DBA), benzo $(a)$ pyrene $(\mathrm{BaP})$, benzo(ghi)perylene $(\mathrm{B} g h i \mathrm{P})$, and indeno(1.2,3$c d)$ pyrene $(\mathrm{IN})$. We used standard reference material SRM 2975 Diesel Particulate Matter (Industrial Forklift) from the National Institute of Standards and Technology (NIST), U.S. Department of Commerce (Gaithersburg, MD). Acetonitrile, dichloromethane, and methanol were of analytical grade and were purchased from Sigma-Aldrich. We used Milli-Q water, obtained with a Milli-Q system (Millipore, Bedford, MA, USA) for dilution.

\section{Sampling Site}

For the presented study we used a diesel engine system from a Skoda Fabia automobile (manufactured in 2007: $2.0 \mathrm{~L}$ volumetric capacity and $130 \mathrm{~kW}$ of power at 1,400 $\mathrm{rpm}$ ) and a $1.4 \mathrm{~L}$ gasoline engine system of $55 \mathrm{~kW}$ manufactured in 2009 (complying with the Euro 4European emission standards). Different diesel fuels used included commercial DIESEL Verva (supplied by the Polish oil company ORLEN), Ultimate (from a British Petroleum station), and Gold (from a Statoil station). We obtained Euro 95 commercial gasoils from three companies (ORLEN, BP, and Statoil). The properties of the fuels used are presented in Table 1. Fuel suppliers assure the high

Table 1. Characteristics of the used fuels.

\begin{tabular}{|c|c|c|c|c|c|c|}
\hline & \multicolumn{3}{|c|}{ Diesel } & \multicolumn{3}{c|}{ Gasoil } \\
\cline { 2 - 7 } & Gold & Verva & Ultimate & Orlen & BP & \\
\hline Cetane index & 55 & 46.0 & $55-60$ & & & 95 \\
\hline Octane index & & & & 95 & 95 & $0.72-0.76$ \\
\hline Density at $15^{\circ} \mathrm{C}\left(\mathrm{g} / \mathrm{cm}^{3}\right)$ & $0.8-0.84$ & $0.82-0.85$ & 0.83 & $0.72-0.76$ & $0.74-0.76$ & Not available \\
\hline Flashpoint $\left({ }^{\circ} \mathrm{C}\right)$ & $<56$ & 55 & 61.5 & $<-10^{\circ} \mathrm{C}$ & $-40^{\circ} \mathrm{C}$ & \\
\hline
\end{tabular}


a)

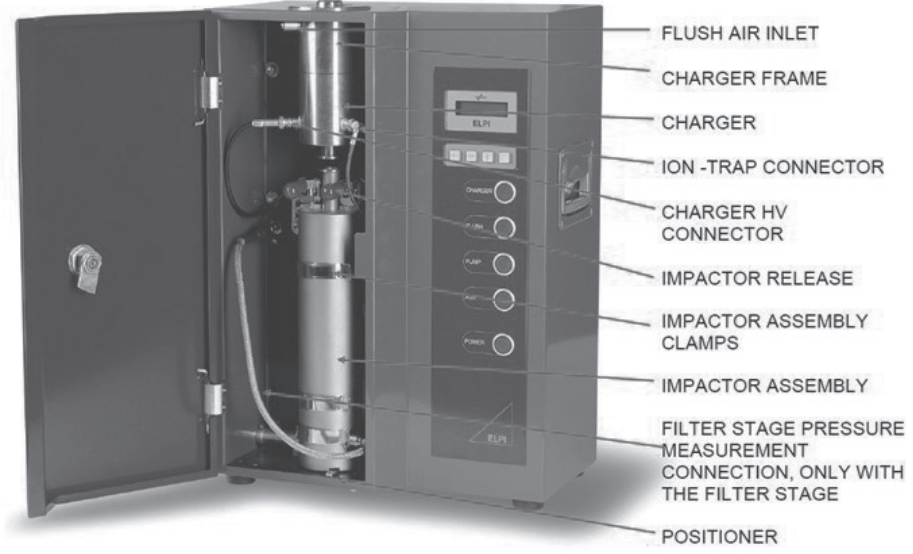

b)

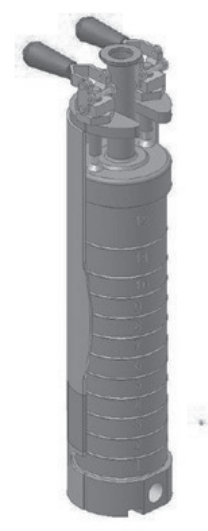

c)

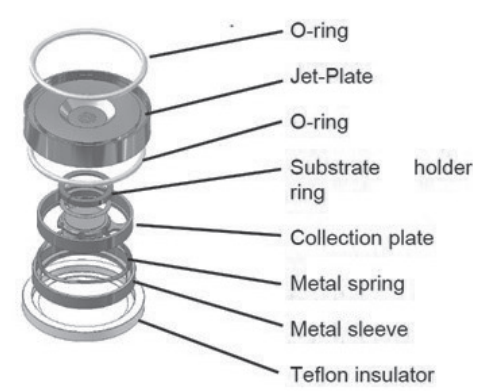

Fig. 1. Sampling system electrical low pressure impactor a), impactor assembly b), one impactor stage c).

quality of their products on their websites and noted that sulphur content was not more than $50 \mathrm{mg} \mathrm{kg}^{-1}$ (for taking care of a car's engine and helping it to run smoother). During the collection of fine particle fraction engines were run at idle speed without load.

\section{Collection of Samples}

PAH samples of particle phase were collected using an ELPI sampling system (Fig. 1) at a temperature below $52^{\circ} \mathrm{C}$ for five days for $4-5$ hours at a flow rate of $30 \mathrm{~L} \cdot \mathrm{min}^{-1}$. Basic parameters of ELPI operations were: impactor output pressure $100 \mathrm{mbar}$, charging voltage $5 \mathrm{kV}$, and charging current $1 \mu \mathrm{A}$. The particles were charged by corona charging and subsequently separated in a low-pressure cascade impactor with 13 electrically insulated collection stages. The measured current signals were proportional to the number concentration and size. By using kernel functions in order to account for the charging efficiency dependency on diameter and for the collection efficiencies of the different stages, the number concentration in every channel could be calculated [20]. During operation with a diesel engine, sampled gas was drawn from the tailpipe and diluted in an ejection double-dilutor (Dekati, Finland) that enabled us to control the dilution ratio at around 64 .

About 7,200-9,000 L of air was passed through the ELPI sampler every day. Only six impactor stages were considered to be essential since they contributed significantly to the measurement. The engine was launched 15 min. before collecting particle-phase PAHs with fuel corresponding to the cycle of measurements.

Particle phase PAHs were collected on aluminum filters weighed on an analytical electronic balance (Mettler Toledo AT261, Switzerland) before and after each collection. Before each weighing the filters were preconditioned in a desiccator for $10 \mathrm{~h}$ to remove moisture. The samples were stored in a refrigerator at $4^{\circ} \mathrm{C}$ for less than seven days until extraction.

\section{Extraction Procedure}

PAHs were extracted from the filters with cold dichloromethane (below $5^{\circ} \mathrm{C}$ ) to prevent their loss by volatilization [21]. A sonic bath was used with closed vials for $30 \mathrm{~min}$. After extraction, samples were evaporated to dryness under a high-purity stream of nitrogen, redissolved in $1 \mathrm{~mL}$ of acetonitrile, and then analysed. The standards were prepared by spiking known amounts of the EPA 16 PAH mixture onto the filter. Therefore, no blank correction was applied.

\section{Chromatographic Analysis}

The samples preconcentrated in nitrogen atmosphere were separated by using the RP-HPLC method (Elite LaChrom with fluorescence detection (FL) of Merck Hitachi, USA) on the column Pinnacle II PAH $15 \mathrm{~cm} x$ $3.2 \mathrm{~mm}$ ID with precolumn $20 \times 3.2 \mathrm{~mm}$ ID, according to the methods mentioned earlier [21]. The flow rate was $0.97 \mathrm{~mL} \cdot \mathrm{min}^{-1}$ and the injection volume was $10 \mu \mathrm{L}$. Elution was performed with a gradient starting from an eluent composition of $50 \%$ acetonitrile in water (up to $5 \mathrm{~min}$ ). The acetonitrile concentration was increased up to $100 \%$ in 25 minutes, and maintained at $100 \%$ for $5 \mathrm{~min}$. The wavelength of the fluorescence detector was altered for each PAH [10]. Data was collected and processed with HP ChemStation software. Limit of detection (LOD), which was determined based on blanks analysis, did not exceed $0.1 \mathrm{ng} \cdot \mathrm{m}^{-3}$. Precision of the method was about $14 \%$ and total uncertainty was less than $28 \%$; correlation coefficient was 0.998 . For validation of the method we used the standard reference material SRM 2975 (diesel particulate matter). There was no significant difference (confidence interval at $95 \%$ using $t$-test) between the obtained results and the certified content. 


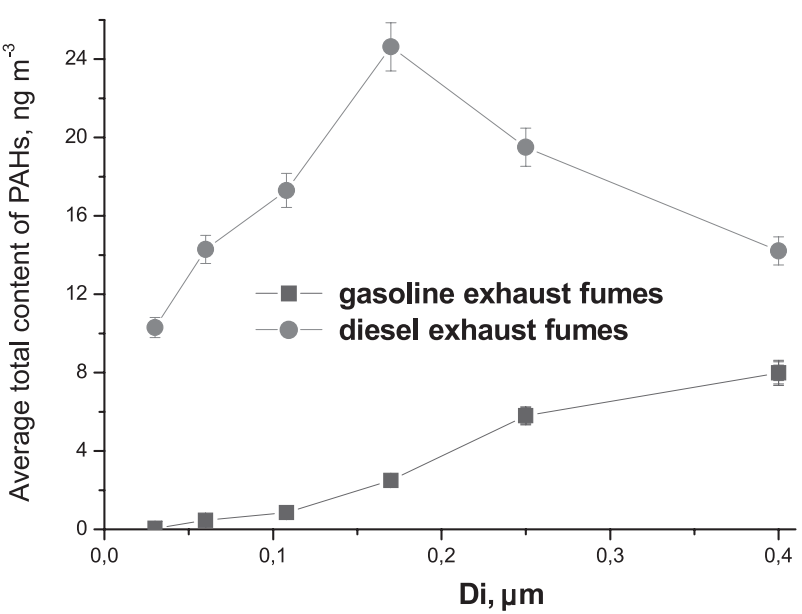

Fig. 2. Distribution of PAHs adsorbed on the fine particles in gasoline and diesel exhaust fumes.

\section{Results and Discussion}

\section{Results for Total PAHs}

Fig. 2 has presented the average distribution of total PAHs adsorbed on the ultrafine particles in gasoline and diesel exhaust fumes. Particles with a diameter below 0.25 $\mu \mathrm{m}$ were mainly detected in the diesel exhaust, which confirmed our earlier results [11]. The average sizes of particles emitted in gasoline exhaust were smaller than particles emitted in diesel exhaust under similar operating conditions.

The distribution of total PAH concentrations on particulate matter emitted from the used car powered by different diesel fuels is presented in Fig. 3a. Gold fuel generated the smallest PAH emissions, followed by Verva and Ultimate fuels. The mean concentrations of total PAHs adsorbed onto the particulate phase (in the rage of 0.03-0.25 $\mu \mathrm{m}$ aerodynamic diameter) using these diesel fuels were $48.3,128.2$, and $83.0 \mathrm{ng} \cdot \mathrm{m}^{-3}$, respectively. While distribution of total PAH content between different sizes of particles emitted in the exhaust of Verva ON has been almost at the same level, and considerable amounts of these compounds were found in 0.11-0.17 $\mu \mathrm{m}$ (35.2 $\left.\mathrm{ng} \cdot \mathrm{m}^{-3}\right)$ and $0.17-0.25 \mu \mathrm{m}\left(24.5 \mathrm{ng} \cdot \mathrm{m}^{-3}\right)$ fractions emitted with Ultimate diesel fuel, which is about $72 \%$ in relation to total content.

The distribution of total concentration of PAHs in ultrafine particulate matter emitted in the exhaust of the petrol engine using oils from different suppliers is presented in Fig. 3b. The obtained results indicate that PAHs present in the last two fractions $(0.17-0.25 \mu \mathrm{m})$ had the highest contribution in the total content of these compounds.

\section{Results for Individual PAHs}

Four PAH compounds were predominantly identified in particulate matter emitted in diesel engine exhaust: fluorene (FL), phenanthrene (PH), pyrene (PY), and benzo(a)pyrene $(\mathrm{BaP})$. The example of the distribution of
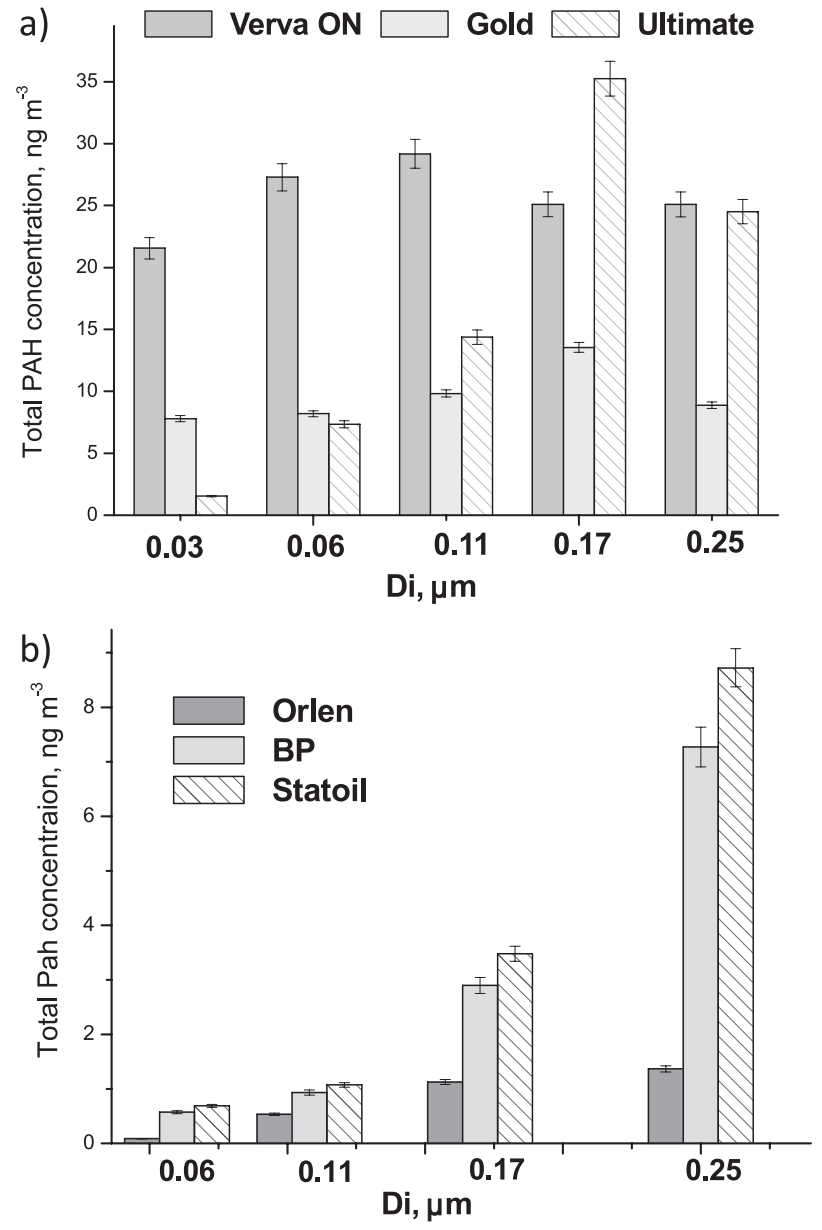

Fig. 3. Distribution of total PAH contents between different sizes of particles emitted in the exhaust of a) diesel and b) petrol engines using different oils.

PAHs identified in individual fractions of particulate matter emitted in diesel engine exhaust running on Verva ON fuel is presented in Fig. 4. On average, the sum of Fl, PH, PY, and $\mathrm{BaP}$ emission rates amounted to $83.7 \%$ of total $\mathrm{PAH}$

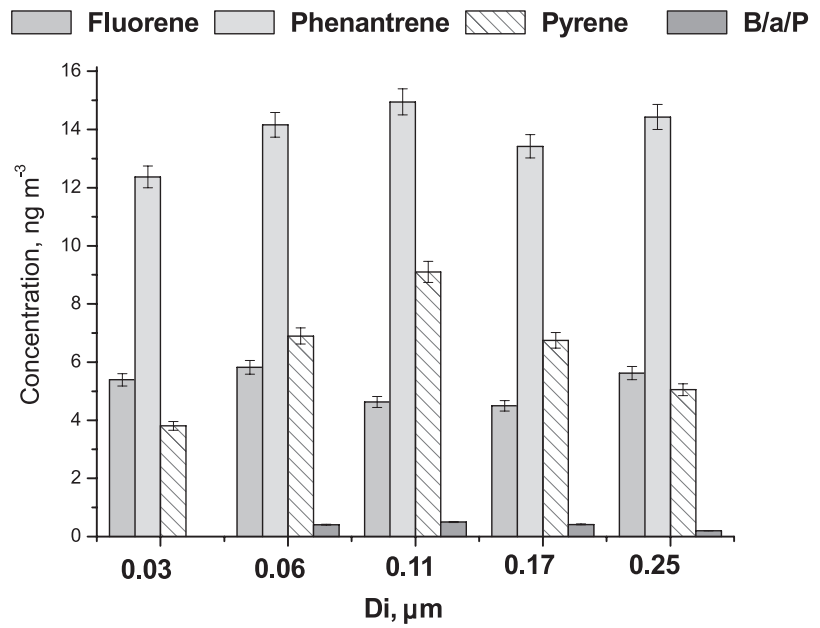

Fig. 4. Concentrations of PAHs identified in ultra-fine particles emitted in the exhaust of diesel (Verva fuel). 


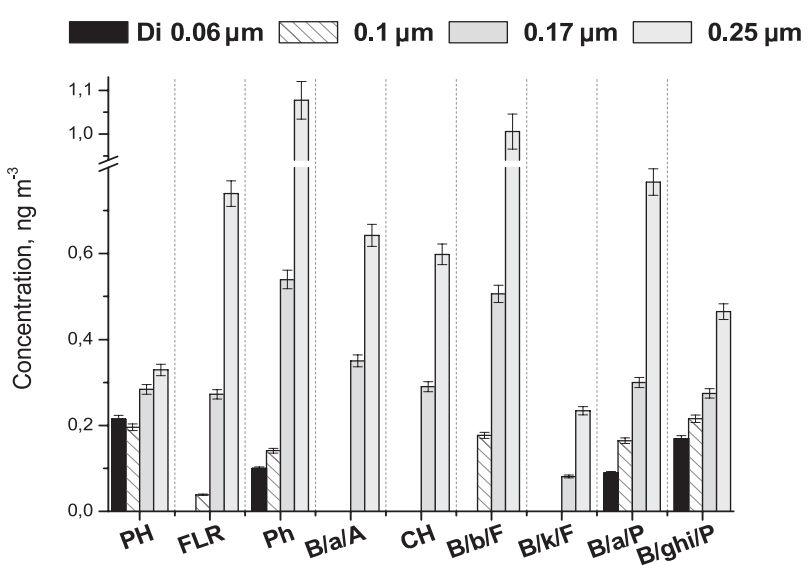

Fig. 5. Emission rates of individual PAH compounds emitted in the gasoline engine exhaust (fuel from BP petrol station).

emissions. Phenanthrene had the highest concentrations $\left(13.4-15.0 \mathrm{ng} \cdot \mathrm{m}^{-3}\right)$ in the tests performed for all collected fractions. Its participation averaged $44.8 \%$ in relation to the sum of total PAH compounds. Similarly, pyrene and fluorine averaged $21.7 \%$ and $16.0 \%$, respectively.

In the case of particulate matter emitted in gasoline engine exhausts, PAH analysis in the collected fractions indicated 12 compounds in the $0.25 \mu \mathrm{m}$ fraction and nine PAHs in the $0.17 \mu \mathrm{m}$ fraction. Fig. 5 presents the profile of PAH compounds collected in different ultrafine fractions of particulate matter from the vehicle exhaust using fuel supplied from the BP petrol station. Phenanthrene $(\mathrm{PH})$ and benzo $(b)$ fluoranthene $(\mathrm{B} b \mathrm{~F})$ dominated in these samples, followed by fluoranthene (FLR) and benzo $(a)$ pyrene (BaP).

Motelay-Massei et al. [22] suggested that indeno(1.2,3$c d$ )pyrene (IN) and dibenzo(ah)anthracene (DBA) could be indicators of vehicular emissions. As diesel exhaust is known to contain more particulate matter than gasoline exhaust, and heavier PAHs are associated with these particles, benzo(ghi)perylene), IN, and DBA have been proposed as markers of diesel emissions [23-25]. Tian et al.
[26] also assigned chrysene $(\mathrm{CH})$ for this purpose. However, $\mathrm{BghiP}$, IN, and DBA, as well as benzo(a)pyrene $(\mathrm{BaP})$ and benzo $(a)$ naphtalene $(\mathrm{BaA})$, were linked with gasoline emission sources [25-27]. Gunawardena et al. [28] concluded that heavy-duty traffic primarily generated five- and six-ring PAHs. They correlated heavy-duty traffic sources with fluorene, dibenz $(a, h)$ anthracene, indeno(1,2,3-cd)pyrene, and benzo(ghi)perylene, whereas acenaphthene, acenaphthylene, phenanthrene, pyrene, benzo $(a)$ pyrene, and benzo(e)pyrene were correlated with the total traffic volume.

Benzo $(a)$ pyrene is considered one of the most carcinogenic PAHs and has been used as an indicator of environmental pollution with polycyclic aromatic hydrocarbons [29]. Table 2 shows the concentrations of this compound in ultrafine particles emitted from diesel and gasoil engine exhaust. In the case of Ultimate diesel and gasoline fuel supplied from Orlen, the contents of $\mathrm{BaP}$ were below the limit of detection in all the collected fractions. From the other side, the highest level of that compound was found in the fume exhaust from Gold diesel fuel.

\section{Conclusions}

Using ELPI and a multi-day cycle of particulate matter sampling enabled us to separate the particulate matter fractions and establish the distribution of $\mathrm{PAH}$ concentrations. The chemical composition of particulate matter emitted in engine exhaust is important due to the issues of environmental pollution. Particulate matter and chemical substances adsorbed onto their surface, such as carcinogenic PAHs, are of great significance because they may have a negative impact on human health due to the place where they accumulate within the human body. The average sizes of particles emitted in gasoline exhaust are smaller than particles emitted in diesel exhaust under similar operating conditions.

Measurements have indicated that the particulate matter in fractions below $0.4 \mu \mathrm{m}$ is emitted in the diesel

Table 2. Concentrations of benzo $(a)$ pyrene (in $\mathrm{ng} / \mathrm{m}^{3}$ ) in ultrafine particles emitted from diesel and gasoil engine exhaust.

\begin{tabular}{|c|c|c|c|c|c|}
\hline & \multicolumn{5}{|c|}{ Aerodynamic diameter $(\mu \mathrm{m})$} \\
\hline & 0.03 & 0.06 & 0.11 & 0.17 & 0.25 \\
\hline \multicolumn{6}{|c|}{ Diesel } \\
\hline Verva & $<\mathrm{LOD}^{*}$ & $0.41 \pm 0.08$ & $0.50 \pm 0.1$ & $0.42 \pm 0.09$ & $<\mathrm{LOD}$ \\
\hline Ultimate & $<\mathrm{LOD}$ & $<\mathrm{LOD}$ & $<\mathrm{LOD}$ & $<\mathrm{LOD}$ & $<\mathrm{LOD}$ \\
\hline Gold & $0.22 \pm 0.04$ & $0.50 \pm 0.1$ & $1.30 \pm 0.26$ & $0.95 \pm 0.19$ & $0.98 \pm 0.20$ \\
\hline \multicolumn{6}{|c|}{ Gasoil } \\
\hline Orlen & $<\mathrm{LOD}$ & $<\mathrm{LOD}$ & $<\mathrm{LOD}$ & $<\mathrm{LOD}$ & $<\mathrm{LOD}$ \\
\hline BP & $<\mathrm{LOD}$ & $<\mathrm{LOD}$ & $0.17 \pm 0.034$ & $0.30 \pm 0.06$ & $0.77 \pm 0.15$ \\
\hline Statoil & $<$ LOD & $0.11 \pm 0.02$ & $0.20 \pm 0.04$ & $0.36 \pm 0.07$ & $0.92 \pm 0.18$ \\
\hline
\end{tabular}

*LOD - limit of detection 
engine exhaust and, to a lesser extent, from the petrol engine. Thus, petrol engines also may be a potential source of environmental pollution with ultra-fine particles. The studies have not indicated the tendency of individual PAH compounds to be adsorbed only on single fractions of particulate matter with specific dimensions.

\section{Acknowledgements}

We prepared our paper based on the results obtained within the "Improvement of Safety and Working Conditions" national program (2014-16) that is coordinated by the Central Institute for Labor Protection - National Research Institute.

\section{References}

1. VU T.V., DELGADO-SABORIT J.M., HARRISON R.M., Review: Particle number size distributions from seven major sources and implications for source apportionment studies. Atmos. Environ. 122, 114, 2015.

2. TOBISZEWSKI M., NAMIEŚNIK J. PAH diagnostics ratios for the identification of pollution emission sources. Environ. Pollut. 162, 110, 2012.

3. FERNANDEZ-GONZALEZ V., CONCHA-GRANA E., MUNIATEGA-LORENZO S., LOPEZ-MAHIA P., PRADA-RODRIGEZ D., Solid-phase microextraction-gas chromatographic - tandem mass spectrometric analysis of polycyclic aromatic hydrocarbons. Towards the European Union water directive 2006/0129 EC, J. Chromatogr. A 1176, 48, 2007

4. BETHA R., BALASUBRAMANIAN R., Emissions of particulate-bound elements from stationary diesel engine: Characterization and risk assessment, Atmos. Environ. 45, 5273, 2011.

5. VILLENEUVE P.J., PARENT M.E, SAHNI V., JOHNSON K.C. Occupational exposure to diesel and gasoline missions and lung cancer in Canadian men, Environ. Res. 111, 727, 2011

6. HIEN T.T., THANH L., KAMEDA T., TAKENAKA N., BANDOW H., Distribution characteristics of polycyclic aromatic hydrocarbons with particle size in urban aerosols at roadside in Ho Chi Minh, Vietnam. Atmos. Environ. 41, 1575,2007

7. HE C., GE Y., MA C., TAN J., LIU Z., WANG C., YU L.X., DING, Y., Emission characteristics of a heavy-duty diesel engine at simulated high altitudes, Sci. Tot. Environ. 409, 3138, 2011.

8. CHIANG H.L., LAI Y.M., CHANG S.Y., Pollutant constituents of exhaust emitted from light-duty diesel vehicles, Atmos. Environ. 47, 399, 2012.

9. KAM W., LIACOS J.W., SCHAUER J.J., DELFINO R.J., SIOUTAS, C., Size-segregated composition of particulate matter (PM) in major roadways and surface streets. Atmos. Environ. 55, 90, 2012.

10. SZEWCZYŃSKA M., POŚNIAK M., DOBRZYŃSKA E., PYRZYNSKA K., BARANIECKA J. Polycyclic aromatic hydrocarbons distribution in fine and ultrafine particles emitted from diesel engine to the air. Pol. J. Environ. Stud. 22, 553, 2013.

11. SZEWCZYŃSKA M., POŚNIAK M., DOBRZYŃSKA
E., Study on individual PAHs content in ultrafine particles from solid fractions of diesel and biodiesel exhaust fumes, e-Journal of Chemistry, 2013, Article ID 528471. http:// dx.doi.org/10.1155/2013/528471

12. KARJALAIMEN P., OIRRJOLA L., HEIKKILÄ J., LÄHDE T., TZAAMKIZOS T., NTZIACHRISTOS L., KOSKINEN J., RÖNKÖ T., Exhaust particles of modern gasoline vehicles: A laboratory and on-road study. Atmos. Environ. 97, 262, 2014

13. ASHRAFUL A.M., MASJUKI H.H., KALAM M.A., Particulate matter, carbon emissions and elemental compositionjs from a diesel engine exhaust fuelled with diesel-biodiesel blends. Atmos. Environ. 100, 463, 2015.

14. WORLD HEALTH ORGANIZATION. International Agency for Research on Cancer, Press release No. 213. 2012.

15. RAVINDRA K., SOKHI R., VAN GRIEKEN R., Atmospheric polycyclic aromatic hydrocarbons: source attribution, emission factors and regulation. Atmos. Environ. 42, 2895, 2008.

16. MATHISSEN M., SCHEER V., VOGT R., BENTER T., Investigation on the potential generation of ultrafine particles from the tire-road interface. Atmos. Environ. 45, 6172, 2011.

17. LIACOS J.W., KAM W., DELFINO R.J., SCHAUER J.J., SIOUTAS C., Characterization of organic, metal and trace element $\mathrm{PM}_{25}$ species and derivation of freeway-based emission rates in Los Angeles. CA. Sci. Total Environ. 435 , 159, 2012.

18. KHAIRY M.A., LOHMANN R., Source apportionment and risk assessment of polycyclic aromatic hydrocarbons in the atmospheric environment of Alexandria, Egypt. Chemosphere 91, 895, 2013.

19. LIU Y., GAO Y., ZHANG C., WANG S., MA L., ZHAO J., LOHMANN, R. Particulate matter, gaseous and particle polycyclic aromatic hydrocarbons (PAHs) in an urban traffic tunnel of China: Emission from on-road vehicles and gasparticle partitioning. Chemosphere 134, 52, 2015.

20. MARJAMÄKI M., LEMMETTY M., KESKINEN J., ELPI response and data reduction. I: Response functions. Aeros. Sci. Technol. 39, 575, 2005.

21. BARANIECKA J., PYRZYNSKA K., SZEWCZYŃSKA M., POŚNIAK M., DOBRZYŃSKA E., Emission of polycyclic aromatic hydrocarbons from selected processes in steel works. J. Hazard. Mater. 183, 111, 2010.

22. MOTELAY-MASSEI A., HARNER T., SHOEIB M., DIAMOND M., STERN G., ROSENBERG, B., Using passive air samplers to assess urbane rural trends for persistent organic pollutants and polycyclic aromatic hydrocarbons. 2. Seasonal trends for PAHs, PCBs, and organochlorine pesticides. Environ. Sci. Technol. 39, 5763, 2005.

23. CALLEN M.S., LOPEZ J.M., MASTRAL A.M., Apportionment of the airborne PM10 in Spain. Episodes of potential negative impact for human health. J. Environ. Monit. 14, 1211, 2012

24. CRISTALE J., SILVA F.S., ZOCOLO G.J., MARCHI M.R., Influence of sugarcane burning on indoor/outdoor PAH air pollution in Brazil. Environ. Pollut. 169, 210, 2012.

25. AYDIN Y.M., KARA M., DUMANOGLU Y., ODABASI M., ELBIR T. Source apportionment of polycyclic aromatic hydrocarbons (PAHs) and polychlorinated biphenyls (PCBs) in ambient air of an industrial region in Turkey. Atmos. Environ. 97, 271, 2014.

26. TIAN Y.Z., LI W.H., SHI G.L., FENG Y.C.,WANG Y.Q. Relationships between PAHs and PCBs, and quantitative source apportionment of PAHs toxicity in sediments from Fenhe reservoir and watershed. J. Hazard Mater. 248, 89, 2013. 
27. GUO H., LEE S.C., HO K.F., WANG X.M., ZOU S.C., Particle-associated polycyclic aromatic hydrocarbons in urban air of Hong Kong. Atmos. Environ. 37, 5307, 2003.

28. GUNAWARDENA J., EGODAWATTA P., AYOKO G.A., GOONETILLEKE A., Role of traffic in atmospheric accumulation of heavy metals and polycyclic aromatic hydrocarbons. Atmos. Environ. 54, 502, 2012.

29. WHO Guidelines for Indoor Air Quality: Selected Pollutants, World Health Organization, Copenhagen 2010. 
